\title{
MARIANAGEM \\ OU \\ DE COMO O PASSADO SE FAZ PRESENTE NO FUTURO
}

\section{Marta Morais da Costa}

Coerente com sua posição crítica, Affonso Ávila é um poeta de vanguarda em busca de uma tradição. Herdando do passado uma necessidade premente de descobrir raizes em que se fundamente nossa cultura, busca estabelecer um relacionamento entre passado \& presente, e seu produto, o futuro. Reflexo disto é sua produção poética recente, reunida em Código de Minas \& Poesia Anterior. 1

A regiāo das Minas Gerais é o motivo constante da primeira parte da obra, Código de Minas, sob um enfoque tradição \& modernidade, onde o tratamento estético do tema repousa sobre os postulados concretistas da espacialidade física da palavra e do branco da página e sobre a estrutura verbivocovisual oriunda de Joyce. Porém, não se recusa a aproveitar o material poético tradicional: estrofe, verso, ritmo e o poema "palavra-puxa-palavra", em que o som em aproximação ou diluição é o elemento de relação entre os versos, p.e.:

\section{a realidade é a dos coroas \\ a real idade é a dos coroas \\ a hilaridade é a dos coroas}

( sua filosofia é o civismo

sua filosofia é o cinismo

sua filosofia é o si mesmo)

\section{"Teoria dos Coroas" in Código de Minas.}

Buscando assim, estilisticamente, um termo comum entre passado \& presente, constrói seu universo poético, repousando numa visão crítica e ao mesmo tempo afetiva, relacionada a uma mesma região em tempos históricos diferentes. Os poemas resultantes expressam essa fusão temporal que, segundo Roberto Pontual, é "um passado que, mais do que nunca, insiste ali em vir à modernidade tal como foi, para continuar sendo". E na impossibilidade desta ruptura, porque tradição é "o passado que ainda está passando", 2 no dizer de Edward Lopes e Eduardo Cañizal, está construído um de seus poemas mais expressivos:

1) AVILA, Affonso. Código de Minas \& Poesia Antorior. Rio, Civilizą̧äo Brasileiro, 1969. (Coleşão Poesia Hoje, Sério Poelas Brasileiros, 17). 


\section{PASSAGEM DE MARIANA}

"DEVAGAR... ATENÇÃo, A $200 \mathrm{M}$, etc."

Cartaz de advertência na Rodovia dos Inconfidentes

devagar... atenção

a $200 \mathrm{~m}$.

fiéis saindo

da igreja

devagar... atenção

há 200 anos

fiéis saindo

da igreja

Estruturado numa base antitética: TRADIÇÃO/MODERNIDA$D E$, o poema não resulta num conflito mas antes numa continuidade, numa fusão espácio-temporạl. A utilização da técnica poética medieval (elemento tradição), o paralelismo, aliada à civilização da máquina, à ultra-convencionalidade do cartaz rodoviário $(200 \mathrm{~m}$., devagar - atenção), exprime esta fusz̃o. O paralelismo na Teoria da Informação representa a redundância, lenta e não informativa, to passo que o cartaz é a comunicação e informação em alto grau de rapidez.

Numa mesma situação antitética encontramos a cidade de Mariana, evocando a tradição de uma época de fausto econômico, de efervescência política e de alta religiosidade, expressa por suas inúmeras igrejas. O elemento "há 200 anos" denota a estaticidade e a rotina que se estabeleceram nesta época historicamente determinada. A antítese encontra seu segundo termo na "Rodovia dos Inconfidentes", simbolizando a dinamicidade e fugacidade espacial do mundo contemporâneo que não se detém, não se debruça sobre o passado. Daí a necessidade de um "cartaz de advertência", de parada, de sentir o passado presente no hoje. Portanto não mais oposição mas continuaçāo.

O termo "Inconfidentes" não evoca apenas um passado político mas se opõe \& se liga, por seu radical latino, "fides", aos fiéis de Mariana. Novamente percebe-se a continuidade de uma sifuação, estática e rotineira, "saindo da igreja", para a dinâmica, "Rodovia". A ausência de pontuação, que projeta uma estrofe na outra (o presente no passado) e as projeta, a ambas, num espaço branco que é seu

2) LOPES, Edward \& CANIZAL, Eduardo. Tradiçäo e Vanguarda. Suplemanto Litarírio. S. Paulo, O Estado de S. Paulo, $15(717):$ 6, 25 abe. 1971. 
ponto de convergência: o futuro, corrobora, ainda uma vez, a intenção de unir tradição \& modernidade. Projeção esta composta por dois elementos essenciais, o espaço, "200 m", e o tempo, "200 anos", sendo este último de capital importância por ser. o único dado novo na estrutura das estrofes. Mesmo a mudança aparente no vocábulo "há" denota uma conservação gráfica convencional, de vez que, enunciado, nada o diferencia de "a 200 m.", reforçando assim a idéia de rotina, hábito, herança adquirida e prolongada, expressa pela segunda estrofe.

Observando a diferença tipográfica das estrofes (a primeira em itálico), deduz-se que, de vez que o itálico objetiva chamar a atenção sobre, salientar algo fora do corpo normal da página, funciona também semanticamente ao conotar uma advertência do poeta para um fato normal (2. estrofe) mas que, por ser contínuo (emprego do gerúndio "saindo"), passa normalmente desapercebido e tende a "continuar sendo". Ao aspecto visual (itálico, ausência de pontuação, convenção de tráfego ' $200 \mathrm{~m}^{\prime \prime}$ e espaço em branco) une-se o ritmo todo binário,

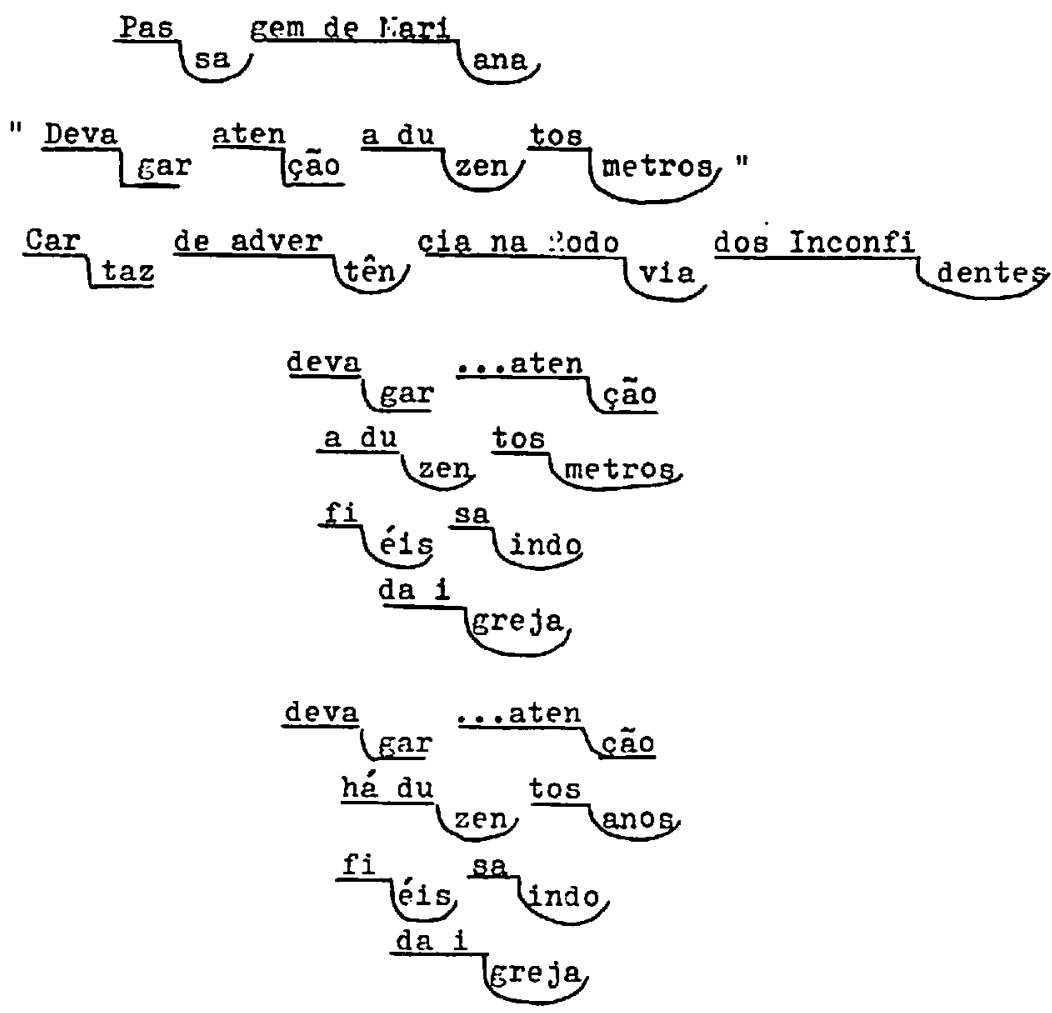


com exceção dos derradeiros versos de cada estrofe, cujo ritmo deve ser completado pelo silêncio, ou seja, pelo que ainda não foi dito ou escrito, pelo futuro.

Desta maneira Affonso Ávila insere-se numa galeria de escritores mineiros, que, presos aos motivos de sua terra natal, lograram alcançar a universalidade além de um lugar de destaque na Literatura Brasileira. De Cládio Manuel da Costa a Murilo Mendes, Drummond e Guimarães Rosa há uma linha de tradição literária mineira a que o poeta de Presença não pôde fugir.

\section{Referências}

AVILA, Affonso. Código de Minas 8 Ponsia Anterior. Rio, Civilização Brasileira, 1969. (Cole. çōo Poesia Hoje, Série Poetas Brasileiros, i7)

LOPES, Edward \& CANIZAL, Eduardo. Tradiçāo e Vanguarda. Suplemento Literírio. S. Paulo, O Estado de S. Paulo, 15 (717): 6, 25 abr. 1971.

RAMOS, Maria Luiza. Fonomenologia da Obra Literária. Rio, Forense, 1969. 